\title{
Neurohistory in Action: Hoarding and the Human Past
}

\section{Citation}

Smail, Daniel Lord. 2014. "Neurohistory in Action: Hoarding and the Human Past." Isis 105 (1) (March): 110-122. doi:10.1086/675553.

\section{Published Version}

doi:10.1086/675553

\section{Permanent link}

http://nrs.harvard.edu/urn-3:HUL.InstRepos:29066985

\section{Terms of Use}

This article was downloaded from Harvard University's DASH repository, and is made available under the terms and conditions applicable to Other Posted Material, as set forth at http:// nrs.harvard.edu/urn-3:HUL.InstRepos:dash.current.terms-of-use\#LAA

\section{Share Your Story}

The Harvard community has made this article openly available.

Please share how this access benefits you. Submit a story.

Accessibility 


\title{
Neurohistory in Action
}

\section{Hoarding and the Human Past}

\author{
By Daniel Lord Smail*
}

\begin{abstract}
A neurohistorical approach begins with the principle that the human brain is relatively plastic and therefore continuously open to developmental and cultural influences. This does not mean that we should treat the brain as a blank slate. Instead, such influences, as they interact with given brain/body systems, can generate unpredictable forward-acting effects. The phenomenon of compulsive hoarding offers a case study of a historically or culturally situated behavior that can be approached in this way. Hoarding appears to be correlated with cognitive lesions or genetic predispositions. Yet although the behavior is very visible today, there is little evidence for the practice in the human past, suggesting that something has triggered the growing prevalence of the phenomenon. Using the coevolutionary approach intrinsic to environmental history, we can treat the rise of compulsive hoarding as an emergent phenomenon generated by the unpredictable ways in which cognitive and endocrinological systems have interacted with a changing material environment. The results of this inquiry suggest not only why history needs cognitive neuroscience but also why neuroscience needs history.
\end{abstract}

I N RECENT YEARS, the phenomenon of compulsive hoarding has drawn a consider1 able amount of media attention as well as academic studies in psychology and neuroscience. The subject has the lurid quality appropriate for reality TV shows, for it draws attention to people who are drowning in newspapers, yogurt cartons, and cats and highlights the wrenching emotions they experience when these things are taken away from them. Although contemporary medical and social science has yet to achieve a full understanding of the condition, some studies have claimed that as much as 5 percent of the U.S. population consists of compulsive hoarders. There are problems with such

\footnotetext{
* Department of History, Harvard University, Cambridge, Massachusetts 02138.

My thanks to Steve Fuller for inviting these thoughts, and enormous thanks to Julia Adeney Thomas, Andrew Shryock, Noreen Tuross, and Aniruddh Patel for reading early drafts. Sarah Richardson offered important bibliographic pointers. I presented earlier versions of this essay to audiences at UCLA and the Australian National University; I am very grateful to my hosts, Lynn Hunt and Ann McGrath, for these invitations, and especially grateful to the members of the audiences for their extraordinarily productive suggestions and comments. The faults that remain are my own.
}

Isis, 2014, 105:110-122

(C2014 by The History of Science Society. All rights reserved.

0021-1753/2014/10501-0005\$10.00 
conclusions, not the least of which is the fuzziness of the definition of the disorder. But even so, there seems to be a lot of hoarding going on. ${ }^{1}$

The phenomenon of compulsive hoarding poses a mischievous challenge to our understanding of humanity and the human past and to the practice of neuroscience itself. Like a range of phenomena, including autism, attention deficit/hyperactivity disorder, and gluten intolerance, compulsive hoarding has the appearance of being an insurgent epidemic in these latter days. Contemplating the putative rise of hoarding, we might be tempted to describe the phenomenon as a social or media construct or, even more, a figment of the psychiatric imagination. And that may be right. But the interpretation will seem thin and insubstantial if you walk into the house of a hoarder and find yourself traversing deep canyons formed by piles of newspaper that reach almost to the ceiling and observing the dry and shriveled bodies of mice who have died between sheets of newsprint. The phenomenon of compulsive hoarding has a grim and hard-edged reality. What is more, the scientific community has persuasively explained hoarding in terms of deficits in cognitive architecture. Some research, for example, has suggested that if a perfectly ordinary person suffers a lesion to a specific part of the brain, she or he is more likely to begin hoarding. ${ }^{2}$ Other scientists have argued that compulsive hoarding runs in families and may even have a genetic component. Among humans, the hoarding allele is located on chromosome 14. ${ }^{3}$ In Doberman Pinschers, apparently, it is found on chromosome $7 .{ }^{4}$

But this is where hoarding begins to make its mischief. For if we accept this conclusion, then it seems that we are bound to conclude, with the evolutionary psychologists, that hoarding is a cognitive universal, found in all the world's populations both past and present. But that, in turn, is singularly hard to believe. Is it plausible to assume that a medieval European peasant who suffered a certain lesion to the prefrontal cortex would have become a hoarder? In a reductio ad absurdum, consider the hunter-gatherer peoples of the Upper Paleolithic. If a person living forty thousand years ago suffered the prohoarding lesion, would he or she have become more prone to hoard the odd bits and things available in the Paleolithic environment? It seems unlikely. A reason for describing Australian aborigines and the !Kung as "affluent," Marshall Sahlins once suggested, arises

\footnotetext{
${ }^{1}$ For an overview see Randy O. Frost, "Introduction," Cognitive and Behavioral Practice, 2010, 17:401-403, doi:10.1016/j.cbpra.2010.01.009. See also "From Dante to DSM-V: A Short History of Hoarding," http:// www.ocfoundation.org/hoarding/dante_to_dsm-v.aspx (accessed 24 Apr. 2013). Compulsive hoarding entered the third edition of the Diagnostic and Statistical Manual of Mental Disorders (DMS-III) as one of the diagnostic criteria of obsessive-compulsive disorder in 1980.

${ }^{2}$ Steven W. Anderson, Hanna Damasio, and Antonio R. Damasio, "A Neural Basis for Collecting Behaviour in Humans," Brain, 2005, 128:201-212; though see Alberto Pertusa, Randy O. Frost, Miguel A. Fullana, Jack Samuels, Gail Steketee, David Tolin, Sanjaya Saxena, et al., "Refining the Diagnostic Boundaries of Compulsive Hoarding: A Critical Review,” Clinical Psychology Review, 2010, 30:371-386.

${ }^{3}$ See Jack Samuels, Yin Yao Shugart, Marco A. Grados, Virginia L. Willour, O. Joseph Bienvenu, Benjamin D. Greenberg, James A. Knowles, et al., "Significant Linkage to Compulsive Hoarding on Chromosome 14 in Families with Obsessive-Compulsive Disorder: Results from the OCD Collaborative Genetics Study," American Journal of Psychiatry, 2007, 164:493-499, doi:10.1176/appi.ajp.164.3.493. See also Alessandra C. Iervolino, Nader Perroud, Miguel Angel Fullana, Michel Guipponi, Lynn Cherkas, David A. Collier, and David MataixCols, "Prevalence and Heritability of Compulsive Hoarding: A Twin Study," ibid., 2009, 166:1156-1161, doi:10.1176/appi.ajp.2009.08121789; and Jane Collingwood, "The Genetics of Compulsive Hoarding," Psych Central.com, http://psychcentral.com/lib/2009/the-genetics-of-compulsive-hoarding (accessed 2 Apr. 2013).

${ }^{4}$ Recent research on Doberman Pinschers at Tufts University has been reported at http://www.tufts.edu/ alumni/magazine/winter2013/think-tank/animal-instincts.html (accessed 21 July 2013).
} 

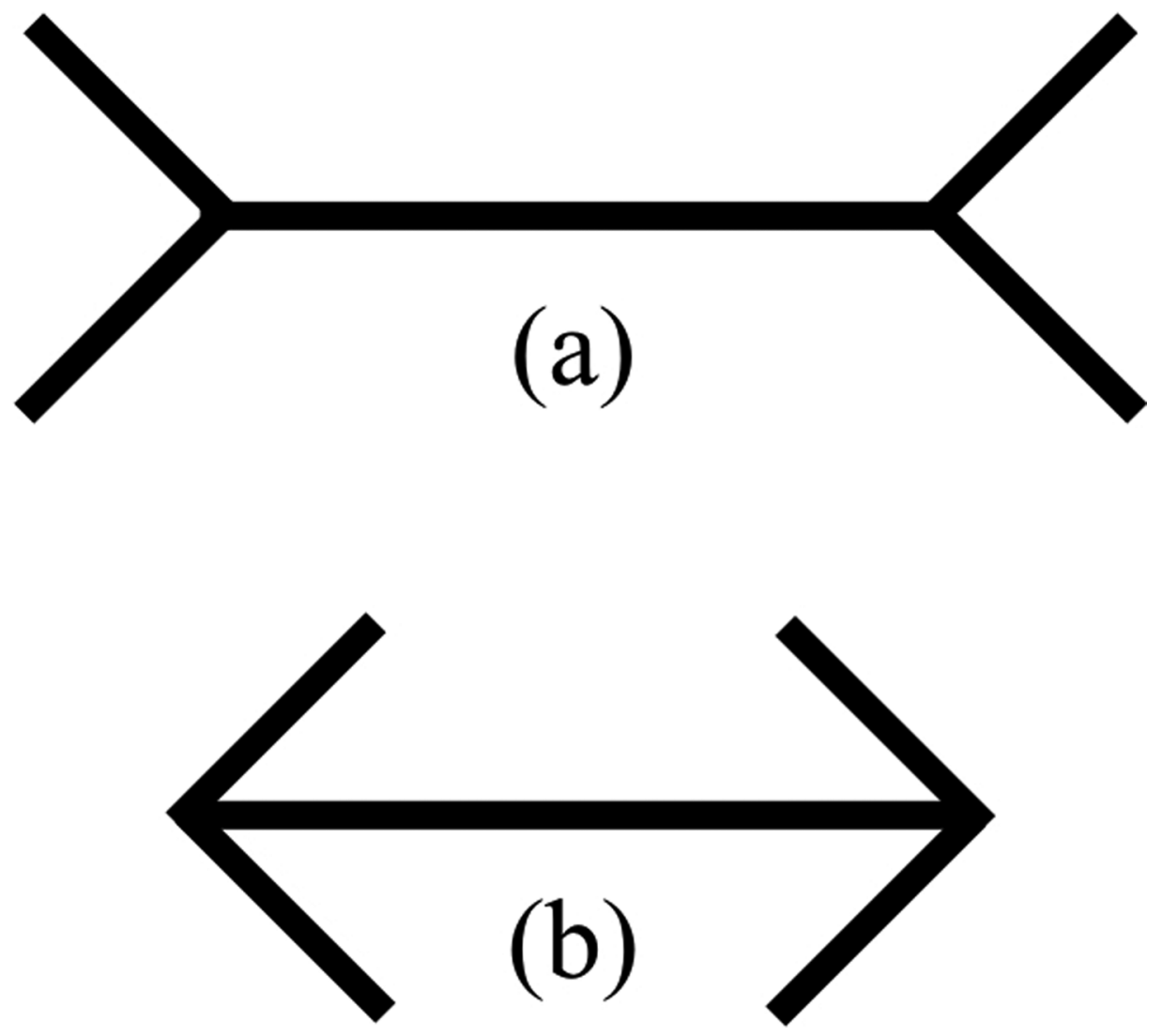

Figure 1. The Müller-Lyer illusion. Composed by Gregory L. Smail.

from the fact that things do not easily cling to them. ${ }^{5}$ Although the subjects of modern ethnographic study are nothing like the peoples of the Upper Paleolithic, the material and ecological contexts they inhabit are quite similar, since both environments are, or were, lacking in the sort of stuff that "our" hoarders hoard, such as packaging material, lint, and bottle caps. Both environments demanded daily and seasonal mobility, which limited the clinginess of things. Even more important, patterns of group living demanded considerable velocity in the circulation of stuff. In such a context, it is difficult to imagine how anyone could have begun to hoard.

As it turns out, there is no particular reason to think that psychological traits necessarily do travel across time and space. The most famous example is the Müller-Lyer illusion. (See Figure 1.) Psychologists have long held—and, oddly enough, some still continue to hold-that the illusion whereby line segment (a) appears to be longer than line segment (b) can be understood as a cognitive universal located in the unchanging architecture of the visual cortex. Yet when cognitive psychologists finally got around to testing subjects other than their own students, they discovered that some of the world's populations are

\footnotetext{
${ }^{5}$ Marshall Sahlins, "The Original Affluent Society," in Stone Age Economics (Chicago: Aldine, 1972), pp. $1-39$.
} 
less likely to see the illusion than others, and the peoples of Amazonia hardly see it at all. M. Segall, D. Campbell, and M. J. Herskovits, who first exposed the cultural situatedness of the Müller-Lyer illusion, have argued that it affects only people who live in carpentered societies - that is to say, in architectural spaces with right angles. ${ }^{6}$

So here's the mischief. On the one hand, compulsive hoarding is a biological or physiological trait. On the other hand, it is a cultural trait tied to a very specific historical context. In the same way that light is both a particle and a wave, hoarding is both something and its opposite. How can that be?

This apparent paradox arises, I believe, from our custom of drawing a line between biology and culture. This approach, which is typical of disciplines like history, cultural anthropology, and even some areas of the history of science, conceives of human history in terms of the "hand-off model." The hand-off model proposes that at some point in the distant past, biological evolution gave way to cultural evolution, and in the process history was born. ${ }^{7}$ The problem, as we have come to realize in recent years, is that the hand-off model is simply wrong. For one thing, the genes are still there, and they make a difference. But as the field of epigenetic research is now showing, gene expression is intimately tangled up with cultural and individual life circumstances. One of the major tasks of the human sciences over the next decade will involve coming to terms with the findings of epigenetics and figuring out how to study humanity without using the hand-off model.

The intellectual mischief generated by the phenomenon of compulsive hoarding is one of many levers that we can use to move the hand-off model out of our habits of analysis. In particular, the case of compulsive hoarding shows how fields like the history of science, history, and anthropology need epigenetics and neuroscience. But even more important, it demonstrates how cognitive neuroscience needs history. Methodologically speaking, it is easy to appreciate why cognitive neuroscience is presentist in its orientation. The science depends on the ability to place subjects in fMRI machines or tag neurochemicals with radioactive isotopes and track their movements in the brain and body. As the findings of Segall et alia have demonstrated, however, there is no reason to assume that any of the findings of cognitive neuroscience will travel across time or culture. Each case has to be proven, not assumed, to be a cognitive universal. Dopamine receptors, stress receptors, and other elements of the human brain may be similar the world over, but the density of receptors in each individual is variable and subject to complex historical and cultural contingencies. Changes in neurons, synapses, or endocrinological systems induced by developmental and cultural circumstances, moreover, can have unpredictable forwardacting effects. The human brain, in other words, is an entity that exists in history. It is important for cognitive neuroscientists to learn how to come to grips with the brain's historicity.

Elsewhere I have described the coming together of history and neuroscience as "neurohistory." ${ }^{\circ}$ Neurohistory assumes that the human brain and the endocrine system are

\footnotetext{
${ }^{6}$ M. Segall, D. Campbell, and M. J. Herskovits, The Influence of Culture on Visual Perception (New York: Bobbs-Merrill, 1966). See also Robert N. McCauley and Joseph Henrich, "Susceptibility to the Müller-Lyer Illusion, Theory-Neutral Observation, and the Diachronic Penetrability of the Visual Input System," Philosophical Psychology, 2006, 19:1-23; and Henrich, Steven J. Heine, and Ara Norenzayan, "The Weirdest People in the World?" Behavioral and Brain Sciences, 2010, 33:61-135, doi:10.1017/S0140525X0999152X.

${ }^{7}$ See Clifford Geertz, The Interpretation of Cultures: Selected Essays (New York: Basic, 1973), p. 92; see also William H. Durham, Coevolution: Genes, Culture, and Human Diversity (Stanford, Calif.: Stanford Univ. Press, 1991), p. 10.

${ }^{8}$ See Daniel Lord Smail, On Deep History and the Brain (Berkeley: Univ. California Press, 2008).
} 
plastic and therefore continuously open to developmental and cultural influences. For this reason, the approach offers a more richly historicized vision of the past than is available through fields such as evolutionary psychology. But this does not mean that the brain can be treated as a blank slate. Instead, neurohistory assumes that developmental and cultural influences, as they interact with brain/body systems, can generate unpredictable forwardacting effects. In practice, this means that we can treat compulsive hoarding as a historically or culturally situated phenomenon that is at the same time correlated with cognitive lesions or genetic predispositions. This interpretation is possible once we learn to identify the coevolutionary dynamics that have characterized the human past and come up with a model for writing history in which the vector for historical change is located in the relationship between humanity and the complex human niche. ${ }^{9}$ By taking a view of the past borrowed from environmental history, we can treat the rise of compulsive hoarding as an emergent phenomenon generated by the unpredictable ways in which cognitive and endocrinological systems have interacted with a changing material environment.

$* \quad * \quad *$

As figures such as Bruno Latour and Ian Hodder have been arguing in recent years, humans and things are entangled in a complex network of actors. ${ }^{10}$ Compulsive hoarding, in other words, should be understood as a network comprising a rather peculiar set of relationships between the actors within the network. A key feature of the entangled relationship between people and things is that it is very old, dating back at least 2.6 million years. As paleoanthropologists and cognitive archaeologists have suggested, humanity itself evolved in Africa in a niche of our own design. This is not to say that other elements of the niche, such as leopards, tubers, grasslands, and rainfall, were insignificant players in the evolution of humanity. But the key element of the niche, as we now understand it, is that it was not the stable "environment of evolutionary adaptedness" posited by evolutionary psychology. Instead, it was and remains primarily a constantly changing social niche, defined by the imperatives of navigating a complex moral world of cooperation, exchange, and punishment. The social niche of the Pleistocene was also a material niche. By crafting tools, weapons, hearths, and a growing array of other material externals, we substantially and continuously altered the material and social contours of the niche in which we subsequently evolved.

By most definitions, the things created by early hominins were cultural in natureand from this it would appear that one can argue that "culture began earlier" than we hitherto thought. But to think of culture in this way is problematic, since it implies that we can separate culture from human biology. This is not so easily done. For one thing, the material externals taken up by early human societies were seen and felt by the human genome over evolutionary time. We find adaptations taking place at the level of the body, as the use of pounding tools and eventually fire led to changes to teeth and gut. ${ }^{11}$ Weapons and other devices took up the task of signaling rank-order location; and as they did, parts of the body such as brow ridges and canines lost some

\footnotetext{
${ }^{9}$ We have explored some of these models for writing history in Andrew Shryock, Daniel Lord Smail, et al., Deep History: The Architecture of Past and Present (Berkeley: Univ. California Press, 2011).

${ }^{10}$ Bruno Latour, Reassembling the Social: An Introduction to Actor-Network-Theory (Clarendon Lectures in Management Studies) (Oxford: Oxford Univ. Press, 2005); and Ian Hodder, Entangled: An Archaeology of the Relationships between Humans and Things (Malden, Mass.: Wiley-Blackwell, 2012).

${ }^{11}$ Richard W. Wrangham, Catching Fire: How Cooking Made Us Human (New York: Basic, 2009).
} 
of their signaling capacity. ${ }^{12}$ Changes like these were encoded directly in the genome. The most important conclusion to have emerged from these and other findings is that there is no such thing as humanity without the material environment in which we lived and evolved. ${ }^{13}$ We have incorporated things into our being in much the same way that our distant eukaryotic ancestors incorporated mitochondria and our genome has absorbed autonomous strands of viral DNA. We have always been post/human cyborgs.

Gene-culture coevolution, as this process is known, has continued and even accelerated up to the present day. The ongoing evolutionary dance between the two partners exposes the flaws inherent in nature/culture thinking. But the human body has also responded to historical change in ways that are not remembered by the genome. Social forms and behavioral patterns sculpt the body in ways that are readily recognized by bioarchaeologists. Since the human diet in recent millennia has been influenced by socioeconomic patterns, for example, the bodies of poor people look different from those of wealthy people. The wearing of shoes has altered the profile of the foot and changed the nature of the gait. When the food-processing industry emerged in the nineteenth century, the morphological consequences of the overall reduction in cumulative bite pressure altered the shape of the developing jaw in individuals. As the jaw shrank, there was increasingly less room for wisdom teeth, causing impaction and hence the need for extraction. Endocrine disrupters such as hormones in chicken feed and BPA in plastic bottles have noticeable effects on the human body. As endocrine disrupters accumulate in the water and food supplies, they are having effects that can be measured epidemiologically. ${ }^{14}$ The human body, in other words, is a kind of contact paper, readily absorbing and revealing impressions left on it by its changing material and social surroundings.

This quality of plasticity is especially characteristic of the brain. Tools and hammers, for example, literally grow into the map of the body when they are used. They become a curious sort of limb, a prosthesis that can be taken off and put on at will. The endocrine system, likewise, responds to its conditions of use. In this vein, consider a recent study in which Lee Gettler and his colleagues surveyed 624 men in the Philippines. ${ }^{15}$ Men with high waking testosterone were more likely to become fathers, but those who became fathers often experienced significant declines in endogenous testosterone. The striking finding is that the decline in testosterone primarily affected men who reported giving three or more hours of child care per day. Since paternal caregiving is defined by social or economic structures, we can predict that levels of male testosterone, across time and

\footnotetext{
${ }^{12}$ This is a classic instance of the Baldwin effect, which proposes that the origin of behavioral or morphological adaptations encoded in the genome can sometimes be traced to behavioral changes acquired by learning. See Bruce H. Weber and David J. Depew, Evolution and Learning: The Baldwin Effect Reconsidered (Cambridge, Mass.: MIT Press, 2003).

${ }^{13}$ This point is made forcefully in John Robb and Oliver Harris, eds., The Body in History: Europe from the Palaeolithic to the Future (Cambridge: Cambridge Univ. Press, 2013)

${ }^{14}$ Clark Spencer Larsen, Bioarchaeology: Interpreting Behavior from the Human Skeleton (New York: Cambridge Univ. Press, 1997); Jane Buikstra, Bioarchaeology: The Contextual Analysis of Human Remains (Boston: Academic, 2006); Tim Ingold, "Culture on the Ground: The World Perceived through the Feet," Journal of Material Culture, 2004, 9:315-340, doi:10.1177/1359183504046896; Daniel Lieberman, The Evolution of the Human Head (Cambridge, Mass.: Harvard Univ. Press, Belknap, 2011); and Nancy Langston, Toxic Bodies: Hormone Disruptors and the Legacy of DES (New Haven, Conn.: Yale Univ. Press, 2010).

${ }^{15}$ Sandra Blakeslee and Matthew Blakeslee, The Body Has a Mind of Its Own (New York: Random House, 2007) (tools as prostheses); and Lee T. Gettler et al., "Longitudinal Evidence That Fatherhood Decreases Testosterone in Human Males," Proceedings of the National Academy of Sciences, 2011, 108:16,194-16,199, doi:10.1073/pnas.1105403108.
} 
space, should track socioeconomic structures: in societies that promote paternal caregiving, levels of waking testosterone should be lower, in the aggregate. Variable aggregate levels of testosterone, in turn, may have forward-acting effects in areas wholly unrelated to parenting, since testosterone can be associated with violence and is also associated with dominance structures.

The variation in testosterone production described by Gettler and his colleagues does not necessarily involve permanent changes in brain structures. But sometimes these changes are indeed permanent. If a mouse is handicapped in such a way as to be the loser in a series of fights with other mice, for example, it enters a condition of chronic stress marked by high levels of stress hormones. ${ }^{16}$ The mouse loses initiative and becomes listless and compliant. ${ }^{17}$ If given access to cocaine, which offers a boost to the dopaminereward system, the mouse will medicate itself at a greater rate than control mice so as to alleviate the feelings of stress. Because the condition of chronic stress is in turn associated with the physical degradation of stress receptors, it can become a permanent condition.

The neurobiology of stress that has come to light in recent studies is interesting to think with because, like testosterone, stress is one of the neurobiological correlates of social rank or position. Some primate societies have developed political systems that leverage stress. ${ }^{18}$ One of the most remarkable discoveries in recent years is that stress can be inherited epigenetically. The maternal licking of rat pups leads to a greater density of stress receptors in the hippocampus, which in turn allows the young rats to handle stress more easily. If rat pups are not licked, their ability to handle stress is reduced. Female rats who were not cared for as pups, in turn, are less likely to lick their own offspring. For several generations, therefore, chronic stress can be transmitted epigenetically from mother to offspring. Lest we use this finding to pile even greater guilt on working mothers, it should be noted that it works for father rats as well. ${ }^{19}$ In the emerging field of historical trauma studies, medical researchers have explored how the epigenetic inheritance of stress can echo down family lines through several generations. ${ }^{20}$

The findings generated by these and other studies describe a vector for historical change that arises from the complex and ongoing dialectic between humanity and the niche we inhabit. We used to think of human history as a kind of species autobiography. We told ourselves that we could narrate this story without regard to other trends. The fact of anthropogenic global warming, and the looming catastrophe that awaits us, illustrates the stunning naïveté of this belief. Our history is necessarily entwined with that of the

${ }^{16}$ J. J. Yap and K. A. Miczek, "Social Defeat Stress, Sensitization, and Intravenous Cocaine SelfAdministration in Mice," Psychopharmacology, 2007, 192:261-273. For an overview see Carl Zimmer, "The Brain: The Switches That Can Turn Mental Illness On and Off," Discover, 2010, 31:26-27.

${ }^{17}$ See Jason S. Snyder, Amélie Soumier, Michelle Brewer, James Pickel, and Heather A. Cameron, "Adult Hippocampal Neurogenesis Buffers Stress Responses and Depressive Behaviour,” Nature, 2011, 476:458-461.

${ }^{18}$ Robert M. Sapolsky, Why Zebras Don't Get Ulcers, 3rd ed. (New York: St. Martin's Griffin, 2004).

${ }^{19}$ Ian C. G. Weaver et al., "Epigenetic Programming by Maternal Behavior," Nature Neuroscience, 2004, 7:847-854, doi:10.1038/nn1276; and David M. Dietz, Quincey LaPlant, Emily L. Watts, Georgia E. Hodes, Scott J. Russo, Jian Feng, Ronald S. Oosting, Vincent Vialou, and Eric J. Nestler, "Paternal Transmission of Stress-Induced Pathologies," Biological Psychiatry, 2011, 70:408-414, doi:10.1016/j.biopsych.2011.05.005. For general surveys of epigenetics see Richard C. Francis, Epigenetics: The Ultimate Mystery of Inheritance (New York: Norton, 2011); and Nessa Carey, The Epigenetics Revolution: How Modern Biology Is Rewriting Our Understanding of Genetics, Disease, and Inheritance (New York: Columbia Univ. Press, 2012).

${ }^{20}$ Karina L. Walters, Selina A. Mohammed, Teresa Evans-Campbell, Ramona E. Beltrán, David H. Chae, and Bonnie Duran, "Bodies Don't Just Tell Stories, They Tell Histories," Du Bois Review: Social Science Research on Race, 2011, 8:179-189, doi:10.1017/S1742058X1100018X; and Jörg Niewöhner, "Epigenetics: Embedded Bodies and the Molecularisation of Biography and Milieu," BioSocieties, 2011, 6:279-298, doi:10.1057/ biosoc.2011.4. 
biosphere. The niche we inhabit carefully tracks our actions and behaviors, in a pattern known to evolutionary biologists as niche construction. ${ }^{21}$ Like any historical actor, the niche responds to our actions in both predictable and unpredictable ways, and it does so regardless of the fact that it lacks both first-order agency and intention. ${ }^{22}$

The pattern is visible everywhere; it is not limited to the fact that sea levels rise as warming temperatures cause ice sheets to melt. The herding of sheep in colonial Mexico, to take a famous example, caused changes in the soil that altered and eventually desiccated the landscape. Mosquitoes began to breed more abundantly when deforestation all over the world caused marshlands to emerge. Water tables subside wherever rivers are channeled. ${ }^{23}$ All these responses have forward-acting effects that alter human societies in their turn. Environmental historians have used the challenges we face today to show how human history makes no sense when it is divorced from the histories of the other systems or actor networks in which we, like all organisms, are entangled. In this model, the subject of history is not humanity, but the vector of change located in the coevolutionary relationship between humanity and the human niche. We need to abandon the view of history in which a solitary humanity is trudging up the side of a mountain on a lonely path.

The niche we inhabit includes the climate, living things, water, chemicals, and so on. But to return to arguments made earlier, it also includes the things that we make and the material surroundings in which we embed ourselves. In the process of adapting to this niche, our bodies, brains, and societies are continuously altered. As we ourselves change, we alter our material environment, producing, exchanging, consuming, and deploying different things in different ways. We have adapted to things, and they have adapted to us, in the same way that the cheetah and the gazelle have continuously adapted to each other in an evolutionary arms race that has produced extraordinarily swift gazelles and slightly swifter cheetahs.

Does this mean that things we are entangled with are alive? Does it mean that things have agency, in the manner in which some scholars are tempted to assign personhood or agency to mosquitoes, trees, and sofas? The urge to accord first-order agency to things is understandable, in light of the recent tendency to assume that the universal ascription of agency is the best way to solve the world's patterns of injustice. Even so, it does have the unfortunate side effect of implying that the only interesting trends over time are those that spring from intention. Anthropogenic global warming offers an interesting philosophical case, because no one involved in the industrialization of nineteenth-century Europe ever intended to release carbon dioxide, and yet the consequences of this act of second-order agency are, arguably, the most pressing problem of the present day. Ditto for the stromatolites who produced the Great Oxygenation Event 2.4 billion years ago and, quite

\footnotetext{
${ }^{21}$ Dipesh Chakrabarty, "The Climate of History: Four Theses," Critical Inquiry, 2009, 35:197-222, doi: 10.1086/596640; F. John Odling-Smee, Niche Construction: The Neglected Process in Evolution (Princeton, N.J.: Princeton Univ. Press, 2003); and Kevin N. Laland and Michael J. O’Brien, "Niche Construction Theory and Archaeology," Journal of Archaeological Method and Theory, 2010, 17:303-322, doi:10.1007/s10816-0109096-6.

${ }^{22}$ I share with Tim Ingold a skepticism about the benefits gained from attributing agency to things; see Tim Ingold, "Materials against Materiality," Archaeological Dialogues, 2007, 14:1-16, esp. pp. 11-12, doi:10.1017/ S1380203807002127.

${ }^{23}$ For these points see, among others, Elinor G. K. Melville, A Plague of Sheep: Environmental Consequences of the Conquest of Mexico (Cambridge: Cambridge Univ. Press, 1994); David Blackbourn, The Conquest of Nature: Water, Landscape, and the Making of Modern Germany (New York: Norton, 2006); Timothy Mitchell, Colonising Egypt (Berkeley: Univ. California Press, 1991); and John Robert McNeill, Mosquito Empires: Ecology and War in the Greater Caribbean, 1620-1914 (New York: Cambridge Univ. Press, 2010).
} 
by accident, very nearly expunged all life on earth. But even if we should hesitate to accord first-order agency to things, it is true that when one contemplates the things that consume the lives of hoarders, it is tempting to treat them as the perfect parasites, entities that have evolved to feed off the surplus energy of their hosts so as to reproduce themselves. Things, we ought to admit, are dangerous.

$$
* * *
$$

The scientific literature has treated compulsive hoarding as a psychological phenomenon that we can explain solely in terms of deficits in cognitive architecture. The impulse, moreover, has been to assume that what is the case now must always have been the case. The impulse of researchers, accordingly, has been to search for the adaptive logic that explains how this behavior got started. It is not hard to find, since simple hoarding was adaptive in the human past and remains so in the human present. Upper Paleolithic humans, much like arctic jays and squirrels, began to cache food systematically so as to serve as a buffer against uncertainty. In the ninth and tenth centuries, northern Europeans cached coins to preserve them from the ravages of Viking raids. The Vikings themselves made hoards of coins and hacksilver. One could go on. Given the ubiquity of such behavior in the past, it is plausible to link the adaptive hoarding behavior of the past to the maladaptive hoarding of the present. One can argue, with the neuroscientists, that the compulsive hoarding of the present day simply arises from the overactivation of the adaptive instinct to save things.

The argument has a superficial plausibility, and it may turn out to be right. Yet there are problems, not least of which is the question of coming up with an explanation for why the hoarding instinct should be overactivated now. The problem is that the compulsive hoarding of useless things seems to be characteristic of only the last century or two-and primarily the last few decades. ${ }^{24}$ It is possible to imagine a Pleistocene hunter-gatherer hoarding the detritus produced by the knapping of a blade or a citizen of ancient Rome squirreling away a multitude of ceramic potsherds, the Roman equivalent of the yogurt container-but if so, the behavior has gone unnoticed by historians and archaeologists. We might expect to find evidence for compulsive hoarding in the tens of thousands of household inventories extant from later medieval Europe. I have studied a subset of this corpus, finding hundreds of apparently worthless things, such as old wooden planks, broken ceramics, and clothing items that are torn or damaged-and yet not the remotest shred of evidence for hoarding behavior. With the partial exception of linens, the junk found in inventories is typically found in ones or twos, never amassed in hoards. Moreover, the junk is categorized according to customary patterns of spatial ordering - the old plank, used to carry bread dough to the public oven, stands alone in the kitchen, near a single broken jar; the shabby linens are stashed away in chests and coffers in the bedrooms or the dining halls. There was plenty of junk capable of being compulsively hoarded in disordered piles, in other words, but no evidence that it ever was. There are exceptions that probe the rule, of course, such as the documents found in the Cairo Geniza and the printed books in early modern Europe, arguably the first mass-produced objects. ${ }^{25}$

\footnotetext{
${ }^{24}$ The International OCD Foundation suggests that a reference in Dante's Inferno constitutes evidence for hoarding behavior in the past. This is an intriguing observation, but it works only if we are willing to equate compulsive hoarding with avarice - that is to say, the compulsive hoarding of money (which, in point of fact, is tempting).

${ }^{25}$ See Mario Wimmer, Archivkörper: Eine Geschichte historischer Einbildungskraft (Konstanz: Konstanz Univ. Press, 2012); my thanks here to Jacob Soll. It is possible to argue that archives such as the Cairo Geniza
} 
But even the character type of the compulsive hoarder in novels, to the best of my knowledge, is not visible before the nineteenth century.

It is true that we can trace the pattern of obsessive collecting back over a number of centuries. But even if obsessive collecting builds on some of the same neural architecture as compulsive hoarding, the two behavioral patterns have distinctive characteristics. Among other things, a distinguishing feature of collecting behavior is that collections are typically organized and annotated, unlike the random piles of junk that form the typical hoard. In addition, compulsive hoarding is quite distinct from the adaptive hoarding behaviors of squirrels, jays, and Paleolithic humans. The pattern of adaptive human hoarding, for example, is seasonal; alternatively, it is triggered by events, such as rumors regarding the arrival of Vikings. Adaptive hoards, like collections, are gathered and organized: wrapped in skins and sunk deep into anoxic swamps or piled into boxes or coffers and buried in the barn. Adaptive hoarders contemplate their goods with satisfaction. Compulsive hoarders, by contrast, sometimes display little or no interest in their things after the moment of acquisition. Their deep emotional attachments surface only with the threat of removal, which induces tremendous anxiety. Above all, compulsive hoarding behavior is associated with an inability to let go of things. This is wholly different from the adaptive hoarders of food or hacksilver, for their hoards were expressly designed to be eaten or traded.

If compulsive hoarding turns out to be a psychological phenomenon of very recent modernity, as I suspect, how can we explain the growing prevalence of the behavior? And why should it be correlated to deficits in cognitive architecture? We do not know all the answers to these questions, so let me describe instead a research hypothesis.

As things worked their way into bodies and brains in deep human time, they inserted themselves not just into actor networks but also into emotional relationships. Paul Bloom has argued that people are naturally dualistic, an argument founded on the observation that very young children are prone to attribute intention to living things and will register surprise when inert things appear to act. But at the same time, as he puts it, "our system of social understanding overshoots, inferring goals and desires where none exist." Among other things, the act of overattributing goals and desires has had the accidental by-product of generating gods and demons, but it also creates the pathways that allow things to be swept up into human moral systems and occupy positions within networks of actors. ${ }^{26}$ Emotional relationships developed within family and kin groups can be easily displaced onto pets, houses, and things. Our emotional habits are very promiscuous and are capable of settling on anything within the actor network.

The growing emotional entanglement with things, however, was not sufficient on its own to generate the phenomenon of compulsive hoarding. One of the crucial features of ancient and medieval European society, and perhaps most human societies, is the omnipresence of recycling and repurposing. Most societies generate waste products from food processing, heating, and construction, but little trash besides that, since household things typically had exceedingly long lives. In Europe's ancient and medieval past, for example,

result from the instinct to hoard compulsively. Among other things, the Geniza was by all accounts a disorganized heap of documents, similar to the classic compulsive hoard. The difference is that the Geniza hoard was maintained not by a single individual but by generations upon generations of keepers.

${ }^{26}$ Paul Bloom, Descartes' Baby: How the Science of Child Development Explains What Makes Us Human (New York: Basic, 2004); Bloom, "Is God an Accident?" Atlantic, Dec. 2005, http://www.theatlantic.com/ magazine/archive/2005/12/is-god-an-accident/304425/4/ (accessed 21 July 2013) (quotation); and Izzat Jarudi, Tamar Kreps, and Bloom, "Is a Refrigerator Good or Evil? The Moral Evaluation of Everyday Objects," Social Justice Research, 2008, 21:457-469, doi:10.1007/s11211-008-0082-z. 
clothing made of valuable and durable fabric such as wool and silk was repeatedly unstitched, cut down, and remade. Metals and alloys were returned to the forge for reworking. In such a world, what would have happened to someone who suffered the hoarding lesion or possessed the hoarding allele on chromosome 14? We can never know. Having said that, and following the lead of Segall et alia, we might be able to do targeted studies of some of the world's populations to see how the behavior manifests itself not only in wealthy societies full of things but also in societies with fewer things. Hypothetically, one can suppose that people in past societies who had deficits in cognitive architecture might have felt the need for some kind of behavioral therapy, but the argument here is that they would not have settled on a therapy that consists of amassing hoards of old wooden planks, broken ceramics, torn clothing, or worn tablecloths, because the material niche they inhabited did not lend itself to the sequestration of such things.

Compulsive hoarding, in this view, is a product of history. It emerged in the context of the changing material niche generated by modern patterns of industrial production and in particular is associated with the growth of consumption. The rise of consumerism can be treated as a good thing. In this view, the democratization of access to stuff has alleviated poverty and has empowered women and world subalterns alike. The critical history of late capitalism offered by the Frankfurt School and developed by figures like Jean Baudrillard and Slavoj Žižek, by contrast, has suggested a darker vision, wherein the emergence of habits of consumption is nothing less than a trap or an addiction. The debilitating desire to consume, in this view, springs from an unholy alliance between the capitalists who seek to sell and the advertising psychologists who have learned how to manipulate the desires of the helpless masses. The opiate of the masses, in this view, is not religion. It is stuff. The result of this manipulation is an order of power that operates not through commandand-control, still less through surveillance, and instead directly through the nervous system. This was the order of power imagined by Aldous Huxley in his dystopian novel Brave New World. The vexing philosophical question raised by Huxley is whether totalitarian power is evil even in those situations where people happily consent to their own oppression.

The critical history of capitalism is compatible with studies in neuroeconomics suggesting that some shoppers experience a dopamine high at the thought of acquiring new things and can even form addictions to shopping. ${ }^{27}$ As such studies suggest, desire really is being manipulated by the consumer society. But although shopping is far more prevalent than compulsive hoarding, the latter behavior is equally constitutive of capitalist modernity. This creates a problem, because compulsive hoarding cannot be so easily explained in terms of desire. The reason is that hoarding behavior may be associated not primarily with the dopamine-reward system but instead with the serotonin system.28 Serotonin is a neurotransmitter and hormone that does several different things in the body. ${ }^{29}$ In the brain, serotonin highs and lows are associated with confidence and security, on the one hand, and depression and insecurity, on the other. MDMA (Ecstasy), for example, is a serotonin agonist; individuals who take Ecstasy experience euphoria for a while, but once serotonin stored in synapses is depleted, depression and anxiety can set in.

\footnotetext{
${ }^{27}$ Donald W. Black, “A Review of Compulsive Buying Disorder,” World Psychiatry, 2007, 6:14-18.

${ }^{28}$ To be sure, it is not appropriate to isolate the actions of one system from another; see, inter alia, Catherine A. Winstanley et al., "Interactions between Serotonin and Dopamine in the Control of Impulsive Choice in Rats: Therapeutic Implications for Impulse Control Disorders," Neuropsychopharmacology, 2005, 30:669-682.

${ }^{29}$ Most of it, for example, is found in the gut, where it helps stimulate digestion; see Elizabeth A. Wilson, "Gut Feminism," Differences, 2004, 15:66-94, doi:10.1215/10407391-15-3-66.
} 
If hoarding is indeed associated with disruptions to the serotonin system, then things, for hoarders, have in effect become proxy serotonin stimulants. Compulsive hoarders become terribly anxious at the thought of losing the things they hoard. In a sense, the hoard even forms part of the extended body of the compulsive hoarder. One psychologist has reported that hoarders say to him things like, "If I throw too much away, there'll be nothing left of me." ${ }^{30}$

An important feature of compulsive hoarding is that it depends on an economy of trash. The act of throwing something away radically denies the membership of things in the actor network. If you trash something, you conceptualize usefulness as an evanescent rather than an enduring quality of things. Also important is mass production, which creates endless sameness, unlike potsherds, each of which, like a snowflake, is unique. If you attribute personhood and enduring utility to one Tetra Brik container, you will now see it in thousands upon thousands. In this view, compulsive hoarding is an emergent phenomenon of modernity. It is the result of the historically contingent way in which the changing material niche created by modern global capitalism has intersected in unpredictable ways with latent features of cognitive architecture.

$$
* * *
$$

Modern global capitalism, to the extent that it consists of consumer items and associated behavioral patterns, has evolved in a complex and changing neurological niche. Whatever else it has been called, capitalism can be seen as an enormous system for stimulating the reward centers of the human brain. The critics of consumption have argued that the desire to consume has been artificially generated by clever marketing. Yet this cannot be the whole story. At the very least, there is no particular reason to assume that a phenomenon such as shopping addiction arises solely from the pleasure principle. In the same way that the chronically stressed mouse repeatedly self-medicates with cocaine, there are undoubtedly consumers, seeking to cope with a condition of chronic stress, who self-medicate by means of shopping and hoarding.

The phenomenon of compulsive hoarding adds a wrinkle to our understanding of late capitalism. As suggested above, the rise of hoarding springs from the thickening presence of nearly identical things and, above all, from the anxiety generated by the economy of trash. Things, in this model, are substitutes for kin and family. Whether or not they really have agency and personhood, we certainly act as if they do, and that is enough. In the past, we used things creatively as devices for creating, maintaining, and repairing human social relationships. ${ }^{31}$ We have been giving or trading since at least the Upper Paleolithic, when regular networks of long-distance exchange become visible in the archaeological record. In light of this history, what is most peculiar about the compulsive hoarders of the present day is the way in which their things have ceased to circulate, except when coerced by jealous family members and TV reality-show producers. Removed from the patterns of

\footnotetext{
${ }^{30}$ Nina Bernstein, "So Much Clutter, So Little Room: Looking Inside the Hoarder's Lair," New York Times, 31 Dec. 2003, http://www.nytimes.com/2003/12/31/nyregion/so-much-clutter-so-little-room-looking-inside-thehoarder-s-lair.html (accessed 24 Apr. 2013) (psychologist's report). See also, e.g., S. K. An et al., "To Discard or Not to Discard: The Neural Basis of Hoarding Symptoms in Obsessive-Compulsive Disorder," Molecular Psychiatry, 2008, 14:318-331, doi:10.1038/sj.mp.4002129.

${ }^{31}$ I owe these points to Andrew Shryock.
} 
circulation that typically define the biographies of things, the objects found in a hoard have become inalienable. ${ }^{32}$

The phenomenon of compulsive hoarding shows how difficult it can be for some people to create and enforce the hierarchy of use and uselessness, a hierarchy that is essential not just to the economy of trash but to neoliberal economics as a whole. To the extent that the hierarchy of things mirrors the hierarchy of persons, in a world that is now divided into rich and poor, worthy and worthless, it is in fact a very generous and liberal-minded thing to do to accord to newspapers, bottle caps, dust bunnies, and packaging materials, not to mention cats, a dignity that is normally reserved for luxury goods, to treat them as members of the family, and to feel personally diminished by their loss. That we describe hoarding as a disorder, and treat it with pity or contempt, according to our wont, is perhaps, above all, a comment on our own misplaced priorities.

${ }^{32}$ See Annette B. Weiner, Inalienable Possessions: The Paradox of Keeping-While-Giving (Berkeley: Univ. California Press, 1992). 